\title{
Evaluation of Sorghum-Cowpea Intercrop Productivity in Savanna Agro-ecology using Competition Indices
}

\author{
Tajudeen Olusegun Oseni \\ Abubakar Tafawa Balewa University, P.M.B. 0248, Bauchi, Nigeria \\ Horticulture Department, University of Swaziland \\ Luyengo, P.O. Box Luyengo, M205, Kingdom of Swaziland \\ Tel: 268-7660-0146_E-mail: toseni@agric.uniswa.sz
}

\begin{abstract}
The competitive behaviour of sorghum-cowpea intercrops at different planting patterns were studied at the Abubakar Tafawa Balewa University Teaching and Research farm, Bauchi in the northern Guinea savanna of Nigeria during the 2005 and 2006 growing seasons. The treatments comprised of three row arrangements of sorghum/cowpea mixtures; one row of sorghum for one row of cowpea (1S:1C), two rows of sorghum for one row of cowpea $(2 \mathrm{~S}: 1 \mathrm{C})$ and one row of sorghum for two rows of cowpea $(1 \mathrm{~S}: 2 \mathrm{C})$, respectively. Sole crops of sorghum and cowpea were included as check to compare yields of intercropped mixtures. Results indicated that grain and straw yields of both sorghum and cowpea were higher in sole cropping than in the intercropping mixtures. However, the 2S:1C planting arrangement exhibited higher LER, competitive indices values, SPI and MAI (7857.11) compared to the other planting arrangements and the sole crops. From this study, it is inferred that intercropping of sorghum with cowpea at $2 \mathrm{~S}: 1 \mathrm{C}$ planting pattern will give higher income, better land use efficiency and thus enhancing sustainability of crop production than sole culture of each crop species.
\end{abstract}

Keywords: Competition indices, Cowpea, Intercropping, Land equivalent ratio, Planting patterns, Savanna, Sorghum

\section{Introduction}

Cowpea (Vigna unguiculata L. Walp) is an important grain legume in Nigeria which is usually grown as an intercrop with major cereals by traditional farmers in the Nigerian savanna (Elemo et al., 1990). Sorghum constitutes the staple food for the bulk of the Nigerian population in the Sudan and Guinea savanna zones (Andrews, 1972). The idea of sustainable agriculture among others includes the adoption of agricultural practices used in low-input traditional farming such as growing arable crops in mixtures (intercrops). Intercropping of cereals with legumes has been popular in tropics (Hauggard-Nielsen et al., 2001) and rain-fed areas of the world (Banik et al., 2000) due to its various advantages (Chen et al., 2004, Agegnehu et al., 2006). Mixed cropping or intercropping is an important practice in the savanna agro-ecology of Nigeria and is considered as part of the subsistence farming designed to meet the increase in domestic food requirements.

The essential features of intercropping systems are that they exhibit intensification in space and time, competition between and among the system components for light, water and nutrients and the proper management of these interactions. The peasants farmers in Nigeria have developed and improved on the traditional systems of mixed cropping, but have maintained relative yield stability at a low level. Odo (1991) reported that the practice of growing sorghum and cowpea on the same piece of land is one of the most important cropping systems in the Nigerian savanna and more than $80 \%$ of all cultivated sorghum and cowpeas are grown in combination with each other. Different planting patterns for cereal-legume intercropping have been practised by many researchers and farmers, but there are conflicting experimental results on the potential yield advantage of mixed cropping over sole cropping involving cereal and legume mixtures. Similarly, the yield advantage of intercropping has not been so marked in several situations possibly due to the use of supra-optimal plant population proportions and, in some cases, to the use of sub-optimal population proportions for component crops.

Ntare (1990) reported that farmers plant sorghum and cowpea in clusters at relatively wide spacing to avoid yield reduction in both crops. Aggarwal et al (1992) reported that the yield advantage of any intercrop is attributed to below-and above-ground plant interactions which are likely to vary depending upon the temporal and spatial differences in resource use by component crops. Thus, a fundamental understanding of how intercrops capture and use resources would provide a scientific basis of recommending appropriate crop combinations and spatial arrangements at different locations. Willey (1979b) reported that intercrop performance can be improved with 
respect to temporal and spatial complementarities by improving the compatibility of genotypes used as components of the mixture. Staggering the relative planting time of the crops would be an example to account for temporal differences in resource use by the crops. Intercropping is being looked at as an efficient and most economical production system as it not only increase the production per unit area and time but also improve the resource use efficiency and economic standard of farmer in the sub-Saharan Africa. Presently, interest in intercropping is increasing and fast becoming important among the small scale farmers because of their diversified needs and low farm income from the mono-cropping system.

The challenge therefore is to identify crops capable of sustaining their potential yield when grown in specific row arrangements with other crops. Spitters (1983) reported that yield of grain per unit area is an essential measure of mixture performance which represent only a part of total plant biomass and may not fully reflect the result of competition between species in mixture. A number of indices such as land equivalent ratio, relative crowding coefficient, competitive ratio, actual yield loss, monetary advantage and intercropping advantage have been proposed to describe competition within and economic advantages of intercropping systems (Banik et al., 2000). The present study was designed to examine the effect of row planting patterns on different competition indices in sorghum-cowpea intercropping systems for better resources management and higher crop productivity.

\section{Materials and Methods}

\subsection{Experimental design and crop management}

Two field experiments were conducted at the research farm of the Abubakar Tafawa Balewa University, Bauchi, during the rainy seasons (June - October) of 2005 and 2006. The site is approximately located at $10^{\circ} 22^{\prime} \mathrm{N} ; 9^{\circ} 47^{\prime}$ $\mathrm{E}$ and $609.45 \mathrm{~m}$ above sea level in the northern Guinea savanna ecological zone of Nigeria. The physico-chemical analysis of the top soil $(0-25 \mathrm{~cm})$ at the experimental site was carried out in 2005 before the commencement of the study following the methods described by A.O.A.C. (1984), and revealed the following composition:- Sand $82.8 \%$; Silt $6.3 \%$; clay $10.9 \%$ Total Nitrogen, $0.085 \%$; Organic Carbon, $0.48 \%$ Available P (Bray 1) $11.5 \mathrm{mg} \mathrm{kg-1;} \mathrm{pH} \mathrm{(water),} \mathrm{6.3;} \mathrm{C.E.C.,} 2.46 \mathrm{meq} / 100 \mathrm{~g}$ soil; Exchangeable bases (meq/100g soil); Ca $0.49 ; \mathrm{Mg} \mathrm{0.31;} \mathrm{K} \mathrm{0.05;} \mathrm{Mn} 0.08$ and Zn $0.61 \mathrm{mg} \mathrm{kg}-1$. The experimental site was ploughed, harrowed and a basal dose of $100 \mathrm{~kg} \mathrm{NPK}(15-15-15) \mathrm{ha}^{-1}$ was broadcast and incorporated into the soil and then ridged at $0.75 \mathrm{~m}$ apart after the rains were well established. Plantings were done manually at a spacing of $0.45 \mathrm{~m}$ on the ridge for both sorghum and cowpea. Six to ten seeds of sorghum (Sam-sorg 10, an improved local variety maturing in 130-140 days) and three seeds of cowpea (Yar-Itas, a popular local spreading variety maturing in 80-85 days) were planted and both thinned to two plants per hill three weeks after planting (WAP). In the first year (2005), sorghum was planted on 22 June and cowpea on 7 July, while in the second year (2006), sorghum was planted on 20 June and cowpea on 4 July. Additional $\mathrm{N}$-fertilizer in form of urea at $45 \mathrm{~kg} \mathrm{~N} \mathrm{ha}^{-1}$ was applied to sorghum ridges after sowing. The experimental plots were $6.0 \mathrm{~m} \mathrm{x} 4.5 \mathrm{~m}$ and consisted of 8 rows. The treatments consisted of three cropping patterns of sole sorghum, sole cowpea and sorghum/cowpea mixtures arranged in an additive series within the rows of 1:1, 1:2 and 2:1 of the sorghum-cowpea combinations. The trials were laid out in a randomised complete block design and replicated three times. Insect pests particularly the cowpea pod borers (Heliothis spp, Maruca spp) were routinely controlled by spraying Karate ED (7.5\% Pirimi carb) with an electro dyne sprayer at 15 days interval starting from one week after flowering and for a period of 3 consecutive weeks during both years. The plots were weeded manually at 30 and 55 days after planting. At maturity, all plants of each crop were harvested separately from the mixtures in the middle 6 rows, and used for seed and stover/haulm yield determinations. Harvesting was done by cutting the stem immediately above ground when the plants were partially dried in the field. Mature cowpea pods harvested were sundried to a constant weight, threshed, weighed and recorded as grain weight. The fodder left after cowpea pod harvests were cut, sundried and weighed as haulm yield. The sorghum panicles harvested were also sundried until constant weight, and weighed. The stalks left after cutting the sorghum panicles were sundried and weighed.

\subsection{Competitive indices and monetary advantage.}

The competitive behaviour of component crops in different sorghum - cowpea planting patterns was determined in terms of land equivalent ratio, relative crowding coefficient, aggressivity, competitive ratio, system productivity index and monetary advantage index by using the following formulae.

(a) The land equivalent ratio (LER), which measures the effectiveness of intercropping in using the environmental resources compared to sole cropping, was obtained according to Mead and Willey (1980). The LER values were calculated as: $\mathrm{LER}=\left(\mathrm{LER}_{\text {sorghum }}+\mathrm{LER}\right.$ cowpea $)$, where $\mathrm{LER}$ sorghum $=\left(\mathrm{Y}_{\mathrm{si}} / \mathrm{Y}_{\mathrm{ss}}\right)$, and $\mathrm{LER}$ cowpea $=$ $\left(\mathrm{Y}_{\mathrm{ci}} / \mathrm{Y}_{\mathrm{cs}}\right)$, where $\mathrm{Y}_{\mathrm{ss}}$ and $\mathrm{Y}_{\mathrm{cs}}$ are the yields of sorghum and cowpea as sole crops respectively, and $\mathrm{Y}_{\mathrm{si}}$ and $\mathrm{Y}_{\mathrm{ci}}$ are the yields of sorghum and cowpea as intercrops, respectively. 
(b) Relative crowding coefficient $(\mathrm{K})$, which is a measure of the relative dominance of one species over the other in a mixture (Willey and Rao, 1980), was calculated as: $K=\left(K_{\text {sorghum }} \times K_{\text {cowpea }}\right)$, where $K_{\text {sorghum }}=Y_{\mathrm{si}} \times Z_{\mathrm{cp}} /\left[\left(\mathrm{Y}_{\mathrm{ss}}-\right.\right.$ $\left.\left.\mathrm{Y}_{\mathrm{si}}\right) \times \mathrm{Z}_{\mathrm{sp}}\right]$, and $\mathrm{K}_{\mathrm{cowpea}}=\mathrm{Y}_{\mathrm{ci}} \times \mathrm{Z}_{\mathrm{sp}} /\left[\left(\mathrm{Y}_{\mathrm{cs}}-\mathrm{Y}_{\mathrm{ci}}\right) \times \mathrm{Z}_{\mathrm{cp}}\right]$, where $\mathrm{Z}_{\mathrm{sp}}$ and $\mathrm{Z}_{\mathrm{cp}}$ were the proportions of sorghum and cowpea in the mixture, respectively. The crop component that had a higher coefficient was said to be dominant.

If the coefficient of a particular crop species is less than, equal to or greater than 1, then that species has produced less yield, the same yield, or more than "expected", respectively (Willey and Rao, 1980).

(c) Aggressivity (A) is a measure of competitive relationships between two crops in mixed cropping (Willey, 1979). This was expressed according to Dhima et al (2007) as follows: $A_{\text {sorghum }}=\left(Y_{\mathrm{si}} / Y_{\mathrm{ss}} \times Z_{\mathrm{sp}}\right)-\left(Y_{\mathrm{ci}} / Y_{\mathrm{cs}} \times Z_{\mathrm{cp}}\right)$ and $A_{\text {cowpea }}=\left(Y_{\mathrm{ci}} / Y_{\mathrm{cs}} \times Z_{\mathrm{cp}}\right)-\left(\mathrm{Y}_{\mathrm{si}} / \mathrm{Y}_{\mathrm{ss}} \times \mathrm{Z}_{\mathrm{sp}}\right)$. Thus if $\mathrm{A}_{\text {sorghum }}=0$, both crops are equally competitive, if $\mathrm{A}_{\text {sorghum }}$ is positive, then it is dominant and if $\mathrm{A}_{\text {sorghum }}$ is negative, then sorghum is weak.

(d) Competitive Ratio (CR) measures the ratio of individual LERs of the two component crops and the proportion in which they were sown in the mixture. This gives a more desirable competitive ability for the crops and is advantageous as an index over $\mathrm{K}$ and AYL (Dhima et al., 2007). The competitive ratio for sorghum and cowpea in mixture was calculated by the formula proposed by Willey et al (1980) as follows: $\mathrm{CR}_{\text {sorghum }}=$ $\left(\mathrm{LER}_{\text {sorghum }} / \mathrm{LER}_{\text {cowpea }}\right)\left(\mathrm{Z}_{\mathrm{cp}} / \mathrm{Z}_{\mathrm{sp}}\right)$, and $\mathrm{CR}_{\text {cowpea }}=\left(\mathrm{LER}_{\text {cowpea }} / \mathrm{LER}_{\text {sorghum }}\right)\left(\mathrm{Z}_{\mathrm{sp}} / \mathrm{Z}_{\mathrm{cp}}\right)$.

(e) System productivity index (SPI) was calculated as; SPI $=(\mathrm{SA} / \mathrm{LB} \times \mathrm{Lb})+\mathrm{Sa}(\mathrm{Odo}, 1991)$. Where: SPI $=$ System productivity index, $\mathrm{SA}$ and $\mathrm{LB}=$ Mean yield of sorghum and cowpea in sole cropping, $\mathrm{Sa}$ and $\mathrm{Lb}=$ Yield of sorghum and cowpea in intercropping.

(f) The Monetary Advantage Index (MAI) which gives an indication of the economic advantage of the intercropping system was calculated according to Ghosh (2004) as follows: MAI = (monetary value of combined intercrops) (LER - 1) / LER.

Economic values of grain and stover produced were estimated based on the average prevailing prices during 2006 from 3 main markets in Bauchi state. The 2006 prices for sorghum grain was N25/kg; sorghum stalk N1/kg; cowpea grain N85/kg and cowpea fodder N10/kg. Mean data for the two years were subjected to statistical analysis using computer programme Genstat 5 Release 3.2. The standard errors of mean differences (SED) were calculated at $5 \%$ level.

\section{Results and discussion}

\subsection{Grain and stover/haulm yields}

Grain and stover/haulm yields of both sorghum and cowpea were higher in sole cropping than the intercropped mixtures irrespective of the planting patterns (Table 1), presumably due to the absence of competition from companion crop. This agreed with the findings of Odo (1991), Ntare and Williams (1992), Lesoing and Francis (1999), and Ajeigbe et al (2006). Similarly, Mead and Willey (1980) had earlier reported that in a sorghum/cowpea intercrop, not only was the yield of cowpea depressed by sorghum but cowpea also depressed the yield of sorghum. However, Chui and Shibles (1983) attributed the depression in yield of cereal/legume mixtures to shading by cereal of the legume thereby reducing yield. Pal et al (1993) also reported yield reduction in intercropped cereal/legume compared to sole cereal and legume in the Nigerian savanna and that yield reduction due to intercropping depended on the crop component ratios. The highest grain yield of sorghum in the mixture was obtained at 2S:1C planting arrangement but not significantly different from the other planting arrangements. Cowpea yields were generally reduced by intercropping as observed in this study as well as in those of several other workers but the extent of yield reduction was minimal in the $1 \mathrm{~S}: 2 \mathrm{C}$ planting arrangement. Clark and Myers (1994) noted that cowpea in narrow strips yielded less than in wide strips or in mono crop, and attributed the reduction to the fact that in the narrow strips, both of the cowpea were bordered by non-legume, and therefore competition were greater than in the wide strips. The stover/haulm yields of both crops in intercropping followed similar trend as in grain yields. This observation thus reflect an inter-specific relationship of mutual inhibition in which both crops in their mixtures at the various planting patterns yielded less than their potential (expected) yields in monoculture.

\subsection{LER, RCC and SPI of sorghum-cowpea intercrop}

The effect of different planting arrangements on land equivalent ratio (LER), relative crowding coefficient (K) and system productivity index (SPI) were not significantly different (Table. 1). As expected, the partial LER of both crops increased as their proportions increased in the intercropping mixtures at the different planting patterns. The total LER was highest at $2 \mathrm{~S}: 1 \mathrm{C}$, where sorghum and cowpea achieved $70 \%$ and $38 \%$ of their sole yields respectively, indicating a higher biological and economic efficiency. The total LER at 2S:1C was higher but not significantly different from $1 \mathrm{~S}: 1 \mathrm{C}$, both of which had a value greater than 1 . However, the total LER at $1 \mathrm{~S}: 2 \mathrm{C}$ 
planting arrangement was less than 1.0, indicating that there was an intercropping disadvantage at this planting pattern presumably due to high intra and inter specific competitions in the sorghum/cowpea intercropping, where sorghum and cowpea produced $40 \%$ and $55 \%$ respectively, of their sole yields. The average relative crowding coefficient $(\mathrm{K})$ value of sorghum was higher than cowpea, thus indicating its dominance in the mixture and such result is not unexpected since cereals are usually more competitive than legumes. This result is supported by the findings of Banik et al (2000) in chickpea-wheat intercropping. The crowding coefficients were not significantly different at the different planting patterns. However, the total $\mathrm{K}$ value at $1 \mathrm{~S}: 2 \mathrm{C}$ was less than 1, thereby indicating that the crops produced less yields than expected presumably due to inadequate utilization of resources. Willey and Rao (1980) reported that where the relative crowding coefficient of a particular crop species is less than, equal to or greater than 1, then that species produced less yield, the same yield or more than 'expected' yield, respectively. The system productivity index (SPI) which standardized the yield of the secondary crop (cowpea) in terms of the primary crop (sorghum) and also identified the combinations that utilized the growth resources most effectively and maintained a stable yield performance showed that the $2 \mathrm{~S}: 1 \mathrm{C}$ pattern gave the highest value than the other arrangements and monoculture. The values of SPI were higher and largely determined by sorghum intercrop yields which were not much reduced by intercropping with cowpea.

\subsection{A, CR and MAI of sorghum-cowpea intercrop}

Aggressivity (A), competitive ratio (CR) and monetary advantage index (MAI) of sorghum-cowpea mixture in 3 planting patterns are presented in Table 2 . The competitive ability of the component crops in an intercropping system is determined by its aggressivity value. Regardless of the planting patterns, there was a positive sign for sorghum and a negative sign for the intercropped cowpea, indicating that sorghum was dominant while cowpea was dominated. Results showed positive aggressivity for sorghum at $2 \mathrm{~S}: 1 \mathrm{C}$ and $1 \mathrm{~S}: 1 \mathrm{C}$ planting patterns while it proved less competitive and was dominated by cowpea at $1 \mathrm{~S}: 2 \mathrm{C}$ planting pattern. This agreed with the findings of Oroka and Omoregie (2007) who obtained higher aggressivity in cowpea over rice at higher population densities. The competitive ratio which measures the degree with which one crop competes with the other showed that sorghum had higher competitive indices than cowpea in all the planting patterns except $1 \mathrm{~S}: 2 \mathrm{C}$ arrangement. The result of CR corroborates with that of aggressivity which showed that sorghum was more competitive than cowpea. Increasing the density of cowpea in the mixture will elevate its crowding efficiency over sorghum which might eventually result in intercropping disadvantage as observed in this study. The monetary advantage index (MAI) values were positive in all the planting patterns except $1 \mathrm{~S}: 2 \mathrm{C}$. The result showed definite yield and economic advantages in sorghum-cowpea intercropping at $2 \mathrm{~S}: 1 \mathrm{C}$ and $1 \mathrm{~S}: 1 \mathrm{C}$ planting patterns over $1 \mathrm{~S}: 2 \mathrm{C}$ planting pattern and their sole cropping. These results are in contrast to the findings of Singh and Ajeigbe (2002) who reported that sole cowpea crop was more profitable than intercropping with cereals. The highest MAI ( 7 857. 11) was obtained in the $2 \mathrm{~S}: 1 \mathrm{C}$ planting pattern, which implied that the planting pattern was highly economical and advantageous for the mixtures. Dhima et al (2007) reported that if LER and relative crowding coefficient (K) values were higher, then there was an economic benefit expressed with MAI values such as obtained in the present study. Krantz et al (1976) also reported higher monetary returns from systems involving intercropping of legumes and non-legumes compared to sole non-legume cropping which was attributed to better utilization of resources.

\section{Conclusion}

Intercropping is an important practice in the savanna agro-ecology of Nigeria and is considered part of the subsistence farming designed to meet increase domestic food requirements. Over $80 \%$ of sorghum and cowpea grown in Nigeria are grown in mixtures at various planting patterns to increase total grain production, provide diversity of products and reduce economic and environmental risks common in monoculture systems. Sole culture grain and stover/haulm yields exceeded intercropped yields but nonetheless, results showed that mixed cropping increased the land equivalent ratio by $8 \%$ in $2 \mathrm{~S}: 1 \mathrm{C}$ planting pattern over sole cropping, produced higher system productivity index, crowding coefficient and gross monetary returns. However, an average farmer in Nigeria might not be interested in the LER, K, SPI, A or CR of intercropping but rather in the profitability of intercropping one crop with the other (that is, which of the intercropping combinations would generate higher income than the other). In conclusion therefore, for optimum and sustainable productivity and profitability of sorghum-cowpea intercrop combinations, a planting pattern comprising of two rows of sorghum to one row of cowpea (2S:1C) should be adopted in the guinea savanna agro ecology to increase land use efficiency.

\section{References}

Agegnehu, G., Ghizam, A., \& Sinebo, W. (2006). Yield performance and land-use efficiency of barley and faba bean mixed cropping in Ethiopian highlands. Europe Journal Agronomy, 25, 202-207. 
Aggarwal, P.K., Garrity, S.P., Liboon, S.P. \& Morris, R.A. (1992). Resource use and plant interactions in rice-mungbean intercrop. Agronomy Journal, 84, 71-78.

Ajeigbe, H.A., Oseni T.O., \& Singh, B.B. (2006). Effect of planting pattern, crop variety and insecticide on the productivity of cowpea-cereal system in northern guinea savanna of Nigeria. Journal Food, Agriculture and Environment, 4(1), 145-150.

Andrews, D. J. (1972). Intercropping with sorghum in Nigeria. Experimental Agriculture, 8, 139-150.

A.O.A.C., (1984). Official Methods of Analysis. $14^{\text {th }}$ Edition. Association of Official Analytical Chemists, Washington D.C.

Banik, P., Sasmal, T., Ghosal, P.K. \& Bagchi, D.K. (2000). Evaluation of mustard (Brassica compestris var. Toria) and legume intercropping under 1:1 and 2:1 row-replacement series systems. Journal Agronomy and Crop Science, 185, 9-14.

Chen, C., Westcott, M., Neill, K., Wichman, D. \& Knox, M. (2004). Row configuration and nitrogen application for barley-pea intercropping in Montana. Agronomy Journal, 96, 1730-1738.

Chui, J.A.N. \& Shibles, R. (1983). Influence of spatial arrangements of maize on performance of an associated soybean intercrop. Field Crop Research, 8, 187-198.

Clark, K.M., \& Myers, R.L. (1994). Intercrop performance of pearl millet, amaranth, cowpea, soybean and guar in response to planting pattern and nitrogen fertilization. Agronomy Journal, 86, 1097-1102.

Dhima, K.V., Lithourgidis, A.A., Vasilakoglou, I.B. \& Dordas, C.A. (2007). Competition indices of common vetch and cereal intercrops in two seeding ratio. Field Crop Research, 100, 249-256.

Elemo, K.A., Kumar, V., Olukosi, J. O. and Ogungbile, A. O. (1990). Review of Research work on mixed cropping in the Nigerian savanna. Samaru Miscellaneous Paper, 127, Pp.125.

Ghosh, P.K. (2004). Growth, yield, competition and economics of groundnut/cereal fodder intercropping systems in the semi-arid tropics of India. Field Crops Research, 88, 227-237.

Hauggard-Nielson, H., Ambus, P. \& Jensen, E.S. (2001). Evaluating pea and barley cultivars for complementary in intercropping at different levels of soil $\mathrm{N}$ availability. Field Crops Research, 72, 185-196.

Lesoing, G.W. \&. Francis, C.A (1999). Strip intercropping effects on yield and yield components of corn, grain sorghum and soybean. Agronomy Journal, 9, 809-813

Mead, R. \& Willey, R.W. (1980). The concept of LER and advantage in yields from intercropping. Experimental Agric., 16, 217-228.

Ntare, B.R. (1990). Intercropping morphologically different cowpeas with pearl millet in a short season environment in the Sahel. Experimental Agriculture, 26, 41-47

Ntare, B.R. \& Williams, J.H. (1992). Response of cowpea cultivars to planting pattern and date of sowing in intercrop with pearl millet in Niger. Experimental Agriculture, 28, 41-48

Odo, P.E., (1991). Evaluating short and tall sorghum varieties in mixtures with cowpea in Sudan Savanna of Nigeria: LER, grain yield and system productivity index. Experimental Agriculture, 27, 435-441.

Oroka, F.O. \& Omoregie, A.U. (2007). Competition in rice-cowpea intercrops as affected by nitrogen fertilization and plant population. Scientia Agricola (Piracicaba, Braz), 64, 621-629.

Pal, U.R., Oseni, T.O., \& Norman, J.C. (1993). Effect of component densities on the productivity of soybean/maize and soybean/sorghum intercrop. Journal Agronomy and Crop Science, 170: 66-70.

Spitters, C.J.T. (1983). An alternative approach to the analysis of mixed cropping experiments. 1. Estimation of competition effects. Netherlands Journal of Agricultural Science, 31, 1-11.

Willey, R.W. (1979a). Intercropping-Its Importance and Research Needs. Part 1. Competition and yield advantages. Field Crop Abstract, 32, 1-10.

Willey, R.W. (1979b). Intercropping-Its Importance and Research Needs. Part 2. Agronomy and Research Approaches. Field Crop Abstract, 32, 73-85.

Willey, R.W. \& Rao, M.R. (1980). A competitive ratio for quantifying competition between intercrops. Experimental Agriculture, 16, 117-125. 
Willey, R.W., Matarajan, M., Reddy, M.S., Rao, M.R., Nambiar, P.T.C., Kammainan, J. \& Bhatanagar, V.S. (1980). Intercropping studies with annual crops. In J.C. Homeless (Ed) "Better crops for food" (Pp83-97). Ciba foundation symp.

Table 1. Grain and Stover yields, land equivalent ratio (LER) and relative crowding coefficient (K) of sole and mixture of sorghum-cowpea in 3 planting patterns

\begin{tabular}{|c|c|c|c|c|c|c|c|c|c|c|c|}
\hline \multirow{3}{*}{$\begin{array}{l}\text { Planting patterns } \\
\text { Sorghum sole * }\end{array}$} & \multirow{2}{*}{\multicolumn{2}{|c|}{$\begin{array}{l}\text { Grain yields }\left(\mathrm{t} \mathrm{ha}^{-1}\right) \\
\text { sorghum cowpea }\end{array}$}} & \multirow{2}{*}{\multicolumn{2}{|c|}{$\begin{array}{l}\text { Stover yields (t } \\
\left.\mathrm{ha}^{-1}\right) \\
\text { Sorghum cowpea }\end{array}$}} & \multicolumn{3}{|c|}{ Land Equivalent Ratio ( LER) } & \multicolumn{3}{|c|}{$\begin{array}{l}\text { Relative Crowding Coefficient } \\
\text { (K) }\end{array}$} & \multirow{3}{*}{$\begin{array}{l}\text { SPI } \\
\\
3.715 \\
\end{array}$} \\
\hline & & & & & \multicolumn{3}{|c|}{ sorghum cowpea } & \multicolumn{3}{|c|}{ Sorghum cowpea Total } & \\
\hline & 3.715 & 0.000 & 6.780 & 0.000 & 1.000 & 0.000 & 1.000 & 1.000 & 0.000 & 1.000 & \\
\hline Cowpea sole * & 0.000 & 0.860 & 0.000 & 1.095 & 0.000 & 1.000 & 1.000 & 0.000 & 1.000 & 1.000 & 0.860 \\
\hline 1:1Sorghum/cowpea & 2.343 & 0.380 & 3.718 & 0.757 & 0.631 & 0.442 & 1.073 & 1.708 & 0.792 & 1.353 & 4.916 \\
\hline 2:1Sorghum/cowpea & 2.604 & 0.328 & 5.873 & 0.511 & 0.701 & 0.381 & 1.082 & 1.172 & 1.233 & 1.445 & 4.952 \\
\hline 1:2Sorghum/cowpea & 1.470 & 0.471 & 2.264 & 0.894 & 0.398 & 0.548 & 0.946 & 1.321 & 0.605 & 0.799 & 4.326 \\
\hline Mean & 2.139 & 0.393 & 3.952 & 0.721 & 0.577 & 0.457 & 1.034 & 1.400 & 0.877 & 1.199 & 4.727 \\
\hline LSD $(\mathrm{P}<0.05)$ & 1.763 & 0.215 & 5.391 & 0.576 & 0.471 & 0.251 & 0.226 & 0.821 & 0.957 & 1.037 & 1.047 \\
\hline
\end{tabular}

* Sole crop values not included in mean calculation.

Table 2. Aggressivity (A), competitive ratio (CR) and monetary advantage index (MAI) of sorghum-cowpea mixture in 3 planting patterns

\begin{tabular}{|c|c|c|c|c|c|}
\hline \multirow[t]{2}{*}{ Planting patterns } & \multicolumn{2}{|c|}{ Aggressivity (A) } & \multicolumn{2}{|c|}{$\begin{array}{c}\text { Competitive Ratio } \\
\text { (CR) }\end{array}$} & MAI** \\
\hline & sorghum & cowpea & sorghum & cowpea & $\#$ \\
\hline 1:1 Sorghum/cowpea & 0.376 & -0.376 & 1.428 & 0.701 & 6950.51 \\
\hline 2:1Sorghum/cowpea & 1.019 & -1.019 & 3.680 & 0.272 & 7857.11 \\
\hline 1:2Sorghum/cowpea & -0.697 & 0.697 & 0.363 & 2.754 & -5022.63 \\
\hline Mean & 0.233 & -0.233 & 1.824 & 1.242 & 3261.663 \\
\hline $\operatorname{LSD}(\mathrm{P}<0.05)$ & 0.574 & 0.574 & 1.027 & 0.939 & 1154.468 \\
\hline
\end{tabular}

** 1 USD $=115$ Naira ( $)$ (2006 FOREX value) 